\title{
A Practical Model for Desodification of Saline-Sodic Soils of Central Khuzestan Plains, Khuzestan Province
}

\author{
Aslan Egdernezhad1, Heydar Ali Kashkuli², Ebrahim Pazira3 ${ }^{3}$, Hossein Sedghi ${ }^{3}$ \\ ${ }^{1}$ Department of Water Engineering, College of Agriculture and Natural Resources, Science and Research Branch, \\ Islamic Azad University, Tehran, Iran \\ ${ }^{2}$ Department of Water Engineering, College of Agriculture and Natural Resources, Ahvaz Branch, Islamic Azad \\ University, Ahvaz, Iran \\ ${ }^{3}$ Department of Soil Science, College of Agriculture and Natural Resources, Science and Research Branch, \\ Islamic Azad University, Tehran, Iran \\ Email: *kashkulihda@gmail.com
}

Received 20 May 2016; accepted 5 August 2016; published 8 August 2016

Copyright (C) 2016 by authors and Scientific Research Publishing Inc.

This work is licensed under the Creative Commons Attribution International License (CC BY).

http://creativecommons.org/licenses/by/4.0/

(c) (i) Open Access

\begin{abstract}
The most important task in leaching practices is assessment of water quantity required for leaching of saline and saline-sodic soils. Therefore, reliable estimation of the required leaching water quantity is vital for reducing soil salinity to a desirable level. The present study aimed to investigate desodification of saline and sodic soils in central area of Khuzestan Province. Consequently, a large area of 3216 ha with S4A3 salinity/sodicity class in Khuzestan, Iran, was selected to obtain the required data. This experiment was conducted with two treatments and tree replicates. In the first treatment, the experiment was conducted by applying just $100 \mathrm{~cm}$ water depth in four $25 \mathrm{~cm}$ intervals. In the second treatment, $5000 \mathrm{~kg} / \mathrm{ha}$ Sulfuric Acid was applied prior to salt leaching together with leaching water. The intermittent ponding method was conducted with double rings in a rectangular array. The required physical and chemical analyses were performed on the collected data. The leaching water was supplied from Shotait River. Four mathematical models were applied to the collected experimental data to derive a suitable empirical model. The results for large scale applications indicated that the proposed logarithmic model can estimate the capital leaching requirement much than the previously proposed models.
\end{abstract}

\section{Keywords}

Desodification Curve, Saline-Sodic Soils, Salt Leaching, Modeling

\footnotetext{
"Corresponding author.
}

How to cite this paper: Egdernezhad, A., Kashkuli, H.A., Pazira, E. and Sedghi, H. (2016) A Practical Model for Desodification of Saline-Sodic Soils of Central Khuzestan Plains, Khuzestan Province. Open Journal of Geology, 6, 740-744. 


\section{Introduction}

Unstable and degrading environmental issues are major challenges in application of natural resources (water and soil) in recent decades. Soil salinization and sodification are important processes of land degradation, especially in arid and semi-arid areas where the soil is modified by leaching of water soluble salts using high quality water along with addition of amendments as needed. Khuzestan Plain with an area of about 3 million hectares and access to a third of surface water resources in Iran is one of the most important poles of irrigated agriculture. Highly salinized and alkaline soils can be found in these areas due to improper use of soil and water resources and uncontrolled irrigation. These factors are major barriers to agriculture in this region.

Various studies have shown that increased number of measurement points reduced uncertainty of model inputs [1]. The results of physicochemical analyses of soils with electrical conductivity values and low sand and low organic matter have shown that soil modification is time-consuming [2]. Exchangeable Sodium Percentage (ESP) index determines structural stability and class of soil sodification in a vast area [3]. Coke and the Muller [4] found out that ESP alone is not a satisfactory indicator for soil behavior.

According to Heidari [5] and Pazira [6], many scholars have studied soil desalination. However, soil desodification was not studied by many scholars [6]. Mohsenifar et al. [7] studied soil desalination and desodification in Southeast region of Khuzestan Province.

The objectives of this study were to introduce an empirical model to account for reclamation water and to compare the obtained results with some available models.

\section{Materials and Methods}

The studied region is a part of Shoaybiyeh plains located in Khuzestan Province with an area of 15,800 ha. Since about 13,295 ha of all studied area have saline-sodic soil, from low to extreme, it can be argued that salinity and sodicity is the main qualitative limitation of more than $84 \%$ of the region's soils.

In order to perform required experiments, salinity and sodicity maps were studied and Deylam soil in TypicCalciorthids group and Aridisals order with S4A2 salinity-sodicity class (extreme salinity and relative extreme sodicity) before leaching tests was selected as the target soil. In the study zone, the area of Deylam soil series is 6205 ha (more than 39\% of the region's soil). Table 1 and Table 2 present the situation, series, and salinity-sodicity classes of the soils in the study area, and some physical characteristics of the various layers in the soil profiles before leaching.

To desotificate soils, leaching of soluble salts from soil profiles was carried out. The experiment had two treatments and was conducted with three replications. Leaching was performed using the intermittent ponding method and the required water was taken from the Shotait River. Table 3 lists results obtained from the chemical analysis of the water used in both treatments.

In the first treatment, no amendment material was used and the 1 meter depth of water was applied in four

Table 1. Series, salinity and sodicity class and some physical characteristics of the studied soil.

\begin{tabular}{ccccc}
\hline Series name & $\begin{array}{c}\text { Salinity and sodicity class } \\
\text { (before test) }\end{array}$ & $\begin{array}{c}\text { Depth of water table } \\
(\mathrm{m})\end{array}$ & $\begin{array}{c}\text { Hydraulic conductivity } \\
(\mathrm{m} / \text { day })\end{array}$ & $\begin{array}{c}\text { Depth of impervious layer } \\
(\mathrm{m})\end{array}$ \\
\hline deylam & S4A2 & 1.90 & 1.74 & More than $5.3 \mathrm{~m}$ \\
\hline
\end{tabular}

Table 2. Some physical characteristics of different layers of soil profile before leaching process in Deylam soil series.

\begin{tabular}{|c|c|c|c|c|c|c|c|c|c|c|c|}
\hline \multirow{3}{*}{$\begin{array}{c}\text { Row } \\
1\end{array}$} & \multirow{3}{*}{$\begin{array}{c}\begin{array}{c}\text { Sampling } \\
\text { depth (m) }\end{array} \\
0-25\end{array}$} & \multirow{3}{*}{$\begin{array}{c}\text { Soil } \\
\text { texture }\end{array}$} & \multirow{2}{*}{\multicolumn{2}{|c|}{$\begin{array}{l}\text { Soil density } \\
\left(\mathrm{gr} / \mathrm{cm}^{3}\right)\end{array}$}} & \multirow{3}{*}{$\begin{array}{c}\text { Total } \\
\text { prosity } \\
(\%)\end{array}$} & \multirow{2}{*}{\multicolumn{2}{|c|}{$\begin{array}{l}\text { Permeability } \\
\text { (mm/hr) }\end{array}$}} & \multicolumn{3}{|c|}{ Humidity (mass percentage) } & \multirow{3}{*}{$\begin{array}{c}\text { Cumulative } \\
\text { soil moisture } \\
\text { deficit }(\mathrm{cm})\end{array}$} \\
\hline & & & & & & & & \multirow{2}{*}{$\begin{array}{c}\begin{array}{c}\text { Before } \\
\text { leaching }\end{array} \\
10.12\end{array}$} & \multirow{2}{*}{$\begin{array}{c}\begin{array}{c}\text { Filed } \\
\text { capacity }\end{array} \\
24.50\end{array}$} & \multirow{2}{*}{$\begin{array}{c}\begin{array}{c}\text { Wilting } \\
\text { point }\end{array} \\
14.25\end{array}$} & \\
\hline & & & 1.64 & 2.66 & & 2.00 & $\mathrm{~S}$ & & & & \\
\hline 2 & $25-50$ & $\mathrm{SiCL}$ & 1.54 & 2.65 & 42.0 & 1.38 & $\mathrm{~S}$ & 9.91 & 23.35 & 14.50 & 11.07 \\
\hline 3 & $50-75$ & $\mathrm{SiCL}$ & 1.65 & 2.70 & 39.0 & 0.88 & V.S & 20.65 & 21.50 & 14.00 & 11.42 \\
\hline 4 & $75-100$ & $\mathrm{SiC}$ & 1.60 & 2.68 & 40.0 & 0.50 & V.S & 11.11 & 20.25 & 13.25 & 15.08 \\
\hline 5 & $100-125$ & $\mathrm{SiC}$ & 1.70 & 2.66 & 36.0 & 0.63 & V.S & 10.39 & 21.50 & 13.00 & 19.80 \\
\hline 6 & $125-150$ & $\mathrm{SiC}$ & 1.70 & 2.68 & 37.0 & 0.63 & V.S & 12.63 & 23.00 & 15.00 & 24.21 \\
\hline
\end{tabular}


Table 3. Chemical decomposition of the water used to leach out soluble salts from soil profile.

\begin{tabular}{cccccccccccc}
\hline Water source & $\begin{array}{c}\mathrm{EC}_{\mathrm{w}} \\
(\mathrm{ds} / \mathrm{m})\end{array}$ & $\mathrm{pH}$ & $\begin{array}{c}\mathrm{TDS} \\
(\mathrm{mg} / \mathrm{lit})\end{array}$ & $\mathrm{Na}^{+}$ & $\mathrm{Mg}^{2+}$ & $\mathrm{Ca}^{2+}$ & $\mathrm{Cl}^{-}$ & $\mathrm{SO}_{4}^{2-}$ & $\mathrm{HCO}_{3}^{2-}$ & SAR & Wilcox category \\
\hline Shotait River & 1.12 & 8.3 & 720 & 5.55 & 3.20 & 2.80 & 5.85 & 2.60 & 3.30 & 3.20 & $\mathrm{C} 3-\mathrm{S} 1$ \\
\hline
\end{tabular}

Table 4. Calculated values (weight average) for $\left(\mathrm{ESP}_{\mathrm{i}}\right)$ and $\left(\mathrm{ESP}_{\mathrm{f}}\right)$ of saturated soil extract before and after applying different amounts of leaching water (gross) in different soil layers of Deylam soil series (with and without reclamation substances).

\begin{tabular}{|c|c|c|c|c|c|c|c|c|c|c|c|c|}
\hline \multirow{3}{*}{$\begin{array}{c}\text { Row } \\
1\end{array}$} & \multirow{3}{*}{$\begin{array}{c}\begin{array}{c}\text { Sampling } \\
\text { depth (m) }\end{array} \\
0-25\end{array}$} & \multirow{3}{*}{$\begin{array}{c}\text { ESP of saturated soil } \\
\text { extract before leaching } \\
35.64\end{array}$} & \multicolumn{10}{|c|}{ ESP of saturated soil extract after different frequencies of leaching water } \\
\hline & & & \multicolumn{2}{|c|}{$\operatorname{ESP}_{\mathrm{f}}(25)$} & \multicolumn{2}{|c|}{$\operatorname{ESP}_{\mathrm{f}}(50)$} & \multicolumn{2}{|c|}{$\operatorname{ESP}_{\mathrm{f}}(75)$} & \multicolumn{2}{|c|}{$\operatorname{ESP}_{\mathrm{f}}(100)$} & \multicolumn{2}{|c|}{$\mathrm{ESP}_{\mathrm{f}}$ (average) } \\
\hline & & & 5.00 & 4.75 & 4.93 & 3.94 & 3.68 & 3.21 & 2.53 & 1.26 & 4.04 & 3.29 \\
\hline 2 & $25-50$ & 30.45 & 19.49 & 16.81 & 7.42 & 15.24 & 6.46 & 9.64 & 3.29 & 2.91 & 9.17 & 11.15 \\
\hline 3 & $50-75$ & 29.18 & 20.40 & 19.90 & 12.88 & 17.19 & 10.81 & 15.39 & 3.99 & 3.19 & 12.02 & 13.92 \\
\hline 4 & $75-100$ & 26.43 & 22.21 & 20.50 & 21.55 & 18.84 & 18.81 & 17.18 & 16.21 & 14.29 & 19.52 & 17.70 \\
\hline 5 & $100-125$ & 24.18 & 25.21 & 21.98 & 24.26 & 20.96 & 18.11 & 17.73 & 17.17 & 14.91 & 22.10 & 18.90 \\
\hline 6 & $125-150$ & 20.42 & 27.91 & 22.72 & 27.46 & 21.32 & 21.74 & 17.81 & 17.27 & 16.57 & 24.91 & 19.61 \\
\hline 7 & Average & 27.72 & 20.40 & 17.78 & 16.42 & 16.25 & 27.01 & 13.49 & 10.08 & 8.86 & 15.29 & 14.09 \\
\hline
\end{tabular}

0.25-meter intervals. However, in the second treatment, five tons of 95\% sulfuric acid was applied and leaching was then carried out by using irrigation water.

The six double cylinders used in the experiment were arranged 5 meters apart on the perimeter of a circle with a radius of 5 meters. Soil samples were taken from depths of $0-25,25-50,50-75,75-100,100-125$, and 125 - 150 centimeters of the soil profiles before leaching and after application of $25,50,75$, and 100 centimeters of water. The samples were sent to the laboratory for analysis. In each experiment, the electrical conductivity, $\mathrm{pH}$, cation exchange capacity, sodium adsorption ratio, exchangeable sodium percentage, saturation percentage, lime, gypsum, and cations and anions ( $\mathrm{Na}, \mathrm{Ca}, \mathrm{Mg}, \mathrm{Cl}$, sulfate, carbonate, and bicarbonate) in the soil extract solution were measured. The salinity values (electrical conductivity of the soil saturation extract) before, during, and after each water application were determined for the desired horizons in the soil profiles (that is, at the depths of 0 - 25, 0 - 50, 0 - 75, 0 - 100, 0 - 125, and 0 - 150 centimeters) relative to the mean weight calculations for different depths of water applied. The results for both treatments are listed in Table 4.

Since all the water applied may not be used for leaching soluble salts out of soil profiles and some if it may be used to offset the soil moisture deficit, even applying large volumes of water will not result in a chemical equilibrium of the soil with the water used in leaching. To overcome this problem, desalinization values were determined based on the averages of salinity by weight as follows:

$$
X=\frac{D_{l w}}{D_{s}} \quad Y=\frac{E S P_{f}-E S P_{e q}}{E S P_{i}-E S P_{e q}}
$$

$E S P_{i}, E S P_{f}$ are exchangeable sodium percentage of soil saturation extract before and after leaching, $D_{l w}$ the net depth of water for leaching, and $D_{s}$ the depth of the soil layer (m). Actually, $D_{l w}$ represents the depth of water that, after offsetting the moisture deficit in the related layer, leaves it by gravity. Deducting $E S P_{e q}$ from the numerator and denominator of the mentioned fraction will cause the results obtained from the effects of external factors such as the amount of evaporation, the condition of the internal drainage in the soil, the quality of water used for leaching, and the conditions under which the experiment is conducted, to become independent. In fact, this will convert the function from the explicit to the implicit state. After obtaining all the values of the leaching experiments, the required analysis was performed using SPSS, Curve Expert, and Excel. The four mathematical models including the power, exponential, inverse, and logarithmic models were fitted to the desodification values, were analyzed using statistical criteria such as coefficient of determination and standard deviation at the one percent level of significance, and the most suitable Desodification model for the tested soils was determined.

\section{Results and Discussion}

According to analyses as well as fitting four mathematical models i.e. logarithmic, power, exponential and in- 
verse models to the values extracted from $X$ and $Y$ variables, derived from field Desodification experiments in Deylam soil series, exponential model with a determination coefficient of 0.73 and standard error of 0.115 in a significance level of $1 \%$ is the best model for treatment 1 which is shown as follows:

$$
Y=-0.135 \operatorname{Ln} X+0.222
$$

Replacement of related variables results in:

$$
\frac{E S P_{f}-E S P_{e q}}{E S P_{i}-E S P_{e q}}=-0.135 \operatorname{Ln} \frac{D_{l w}}{D_{s}}+0.222
$$

Having relation (), required depth for removing soluble salts from soil profile with a given thickness and a given final salinity of saturated soil extract is computed as follows:

$$
\begin{gathered}
D_{l w}=D_{s} \cdot \exp \left[\left(\frac{E S P_{f}-E S P_{e q}}{E S P_{i}-E S P_{e q}}\right)-0.222 /(-0.135)\right] \\
E S P_{f}=\left[\left(E S P_{i}-E S P_{e q}\right) \cdot\left(-0.135 \operatorname{Ln} \frac{D_{l w}}{D_{s}}+0.222\right)\right]-E S P_{e q}
\end{gathered}
$$

According to analyses as well as fitting different empirical models, logarithmic model with a definition coefficient of 0.65 and standard error of 0.113 in a significance level of $1 \%$ is the best model for treatment 2 which is shown as following:

$$
Y=-0.110 \operatorname{Ln} X+0.210
$$

Replacement of related variables results in:

$$
\frac{E S P_{f}-E S P_{e q}}{E S P_{i}-E S P_{e q}}=-0.110 \operatorname{Ln} \frac{D_{l w}}{D_{s}}+0.222
$$

According to Figure 1 and Figure 2, in the soil series removing salts is easier in treatment 1 compared with treatment 2. Comparison of the curves show that in the case of applying sulfuric acid as reclamation substance, more leaching water is required compared with the case of no use of sulfuric acid.

From the curves shown in Figure 1 and Figure 2, final exchangeable sodium percentage of soil $\left(E S P_{f}\right)$ and required net depth of water for reclamation $\left(D_{1 w}\right)$ can be estimated. It should be noted that if one wish to estimate total required depth of leaching water, soil water deficit in the considered soil layer, surface evaporation and precipitation amount should be taken into account in the calculations and planning of leaching process.

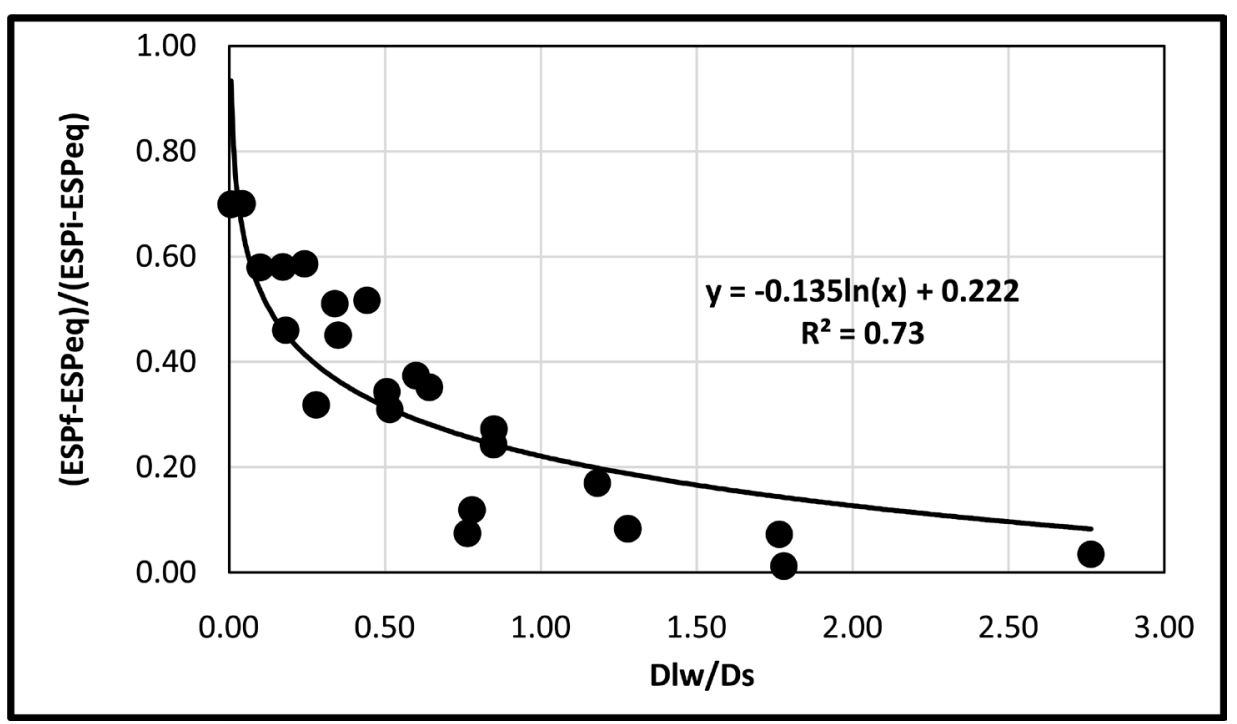

Figure 1. Soil desodification curve in Deylam soil series (treatment 1). 


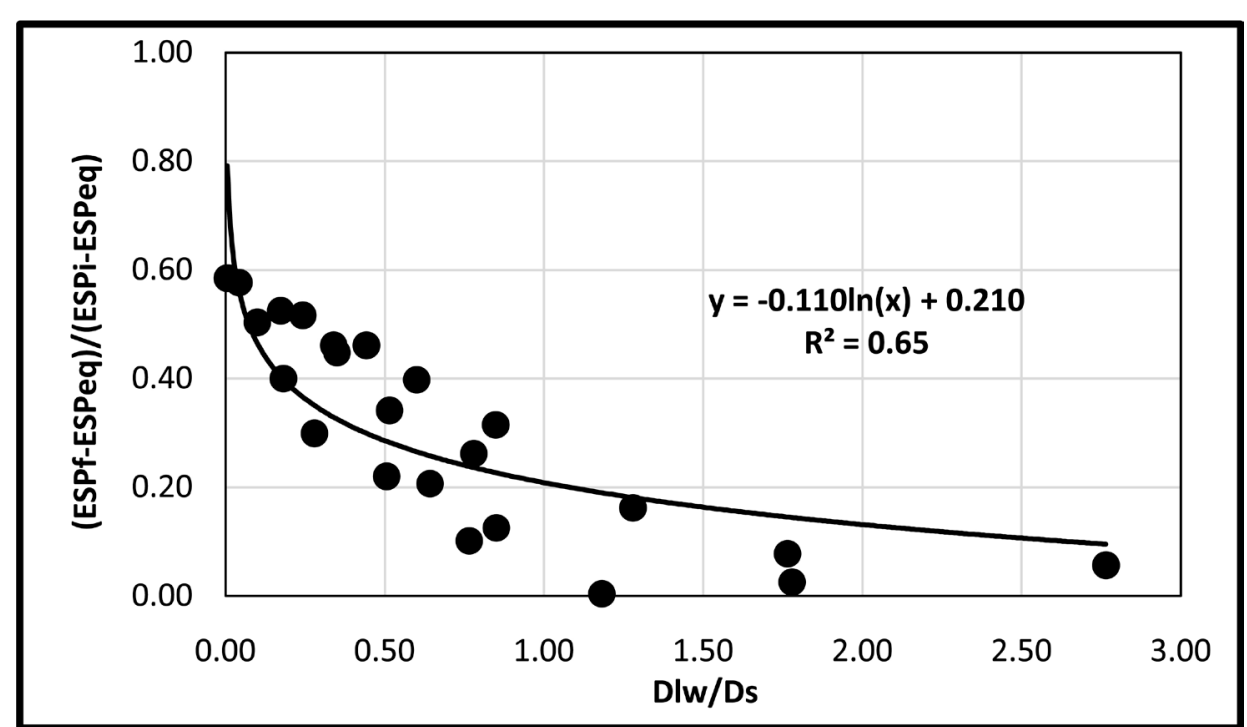

Figure 2. Soil desodification curve in Deylam soil series (treatment 2).

However, the curves are valid only for the region's soil and within initial electrical conductivity limits of 35.55 $\mathrm{dS} / \mathrm{m}$ to $94.46 \mathrm{dS} / \mathrm{m}$ and exchangeable sodium percentage (ESP) of 26.81 to 31.36 .

\section{References}

[1] Asensioa, M.I., Ayusob, B., Ferraguta, L. and Sangalli, G. (2008) Numerical Methods for Modelling Leaching of Pollutants in Soils. Advances in Engineering Software, 38, 429-438.

[2] Shi, Z., Cheng, J.L., Huang, M.X. and Zhou, L.Q. (2006) Assessing Reclamation Levels of Coastal Saline Lands with Integrated Stepwise Discriminant Analysis and Laboratory Hyperspectral Data. Journal of Pedosphere, 16, 154-160.

[3] Chartes, C.J. (1993) Sodic Soils: An Introduction to Their Formation and Distribution in Australia. Australian Journal of Soil Research, 31, 751-760. http://dx.doi.org/10.1071/SR9930751

[4] Cook, C.D. and Muller, W.J. (1997) Is Exchangeable Sodium Content a Better Index of Soil Sodicity than Exchangeable Sodium Percentage: A Reassessment of Published Data. Journal of Soil Science, 162, 342-349. http://dx.doi.org/10.1097/00010694-199705000-00004

[5] Haidari, N. (1994) Studing of Leaching Models and Determine Leaching Efficiency at Saline and Sodic Soils. M.Sc. Thesis, Department of Irrigation and Reclamation Engineering, Faculty of Agriculture, University of Tehran, Karaj, 125 p. (In Persian)

[6] Pazira, E. (2005) Application and Evaluation of Empirical and Theoretical Leaching Models of Salt-Affected Soil. Iranian Water Resources Management Company, Volume 276, 275 p. (In Persian)

[7] Mohsenifar, K., Pazira, A. and Najafi, P. (2006) Evaluation Different Type of Leaching Models in Two Pilots of South East Khoozestan Province. $18^{\text {th }}$ World Congress of Soil Science, Philadelphia. 


\section{Submit or recommend next manuscript to SCIRP and we will provide best service for you:}

Accepting pre-submission inquiries through Email, Facebook, LinkedIn, Twitter, etc.

A wide selection of journals (inclusive of 9 subjects, more than 200 journals)

Providing 24-hour high-quality service

User-friendly online submission system

Fair and swift peer-review system

Efficient typesetting and proofreading procedure

Display of the result of downloads and visits, as well as the number of cited articles

Maximum dissemination of your research work

Submit your manuscript at: http://papersubmission.scirp.org/ 